\title{
Impact of Target Diameter Harvesting on Spatial and Temporal Pattern of Drought Risk in Forest Ecosystems Under Climate Change Conditions
}

\author{
B. Ahrends ${ }^{*}, 1$ C. Penne ${ }^{2}$ and O. Panferov ${ }^{3}$ \\ ${ }^{I}$ Georg-August-University, Soil Science of Temperate and Boreal Ecosystems, Büsgenweg 2, D-37077 Göttingen, \\ Germany \\ ${ }^{2}$ Leibniz University Hannover, Institute of Soil Science, Herrenhäuser-Str.2, D-30419 Hannover, Germany \\ ${ }^{3}$ Georg-August-University, Bioclimatology, Büsgenweg 2, D-37077 Göttingen, Germany
}

\begin{abstract}
Forests are influenced by many disturbances, especially drought, windthrow, pest attacks, air pollution, and forest management. The climate change results in increasing frequency of weather extremes which will probably cause drought stresses in European forest ecosystems. By integrating several new features within the BROOK90 model, smallscale coupled process-based modeling was carried out for different climate and target diameter harvesting scenarios in the region of Solling, Germany. The results show considerable increment of drought risks towards 2100 compared to "present climate conditions", caused by changes in precipitation and increase of mean air temperature. Beyond this it is shown that for the Solling site the changes of structure and microclimate produced by target diameter harvesting result in a decrease of drought stress and could be implemented to mitigate drought events.
\end{abstract}

Keywords: Target diameter harvesting, drought stress, climate change, BROOK90, water-balance model.

\section{INTRODUCTION}

In the development of forest management strategies the timber production, the maintenance of biological diversity, and soil and water protection are all considered equally important targets $[1,2]$. Sustainable forest management (SFM) is the overall objective of the Land Forest Service and private forest holdings today. The key experience has been recognizing the importance of the SFM for the natural self-regulation capacity of the forest ecosystem [3]. According to [4] it is possible to achieve biodiversity, nutrient cycling, and stability gains in an uneven-aged forest stand. Even-aged clear felling and natural regeneration management are commonly applied in practice during the last decades in Germany. Uneven-aged natural regeneration through selective felling is rare, but this method is assumed to yield important ecological benefits [5]. It is ecologically and economically worthwhile to harvest older trees with a greater wood volume [6]. This way the forests could store higher amounts of carbon and develop more quality timber. In selection harvest systems, individual trees or small groups of trees are harvested at periodic intervals. The selection is primarily based on their physical condition or degree of maturity [7]. Also the target diameter harvesting (TDH) regime allows avoiding the whole clearcut areas as a method of final harvesting when individual trees have reached a certain diameter rather than when stands have reached rotation age [8]. So the harvest takes place temporally staged (single-stem), which lets the forest to remain a forest (continuous cover forestry). The choice of this regime however complicates forest operations in the whole and the wood harvest in particular.

*Address correspondence to this author at the Georg-August-University Soil Science of Temperate and Boreal Ecosystems, Büsgenweg 2, D-37077 Göttingen, Germany; Tel: +49-0551-393546; Fax: +49-0551-393310;

E-mail: bahrend@uni-goettingen.de
Along with human impacts the natural disturbances play an important role in restructuring of plant communities [9]. Wind damage, i.e. windthrow or stem break, is the major natural disturbance that can occur in European forests. The positive feedback of windthrow events on wind forcing in a forest gap was demonstrated by [10]. Another natural disturbance is the drought-induced mortality [11]. The climate projections suggest that the risk of damages for trees will increase as a result of the predicted climatic warming. The regional climate model simulations for the next 100 years project the increase of annual mean temperature (AMT) for Germany within the range between $2{ }^{\circ} \mathrm{C}$ and $3{ }^{\circ} \mathrm{C}$, when using rather mild scenarios SRES B1 and A1B [12]. Heat waves and drought would increase in intensity, frequency and duration [13-15]. Besides the projected higher probabilities of severe storms [16-18], these climatic changes will expose German forest ecosystems to environmental conditions that differ from those experienced in the past [19]. It was pointed out that forest management using adequate decision support systems (DSS) can considerably reduce the risk of damages [20] including drought. The DSS "Forest and Climate Change" which is currently being developed at the Göttingen University is aimed to provide a tool for the quantitative assessment of biotic and abiotic risks of forest ecosystems under the conditions of changing climate [19]. An improved understanding of damages is essential for addressing the environmental and policy implications of climate variability and global change. Therefore, the objective of this study is to assess the spatio-temporal variability of TDH regime on drought risk for two tree species (spruce and beech) typical for Germany under the projected climatic conditions of SRES A1B and B1 in the Solling area. 


\section{MATERIALS AND METHODOLOGY}

\section{Investigation Area}

The investigation area within the limits of $51.5^{\circ} \mathrm{N}$ to $52.1^{\circ} \mathrm{N}$ and $9.3^{\circ} \mathrm{E}$ to $9.9^{\circ} \mathrm{E}$, i.e. about $3600 \mathrm{~km}^{2}$ encloses the Solling highlands. The Solling is a mountain range in the 'Weserbergland' on the north-western border of the central German uplands, covering the sub-montane and the montane zone up to $550 \mathrm{~m}$ a.s.l. It is located between the basins of the river Weser (west) and Leine (east). The hills of the eastern bank are formed mainly of sandstone, which is known locally as 'Buntsandstein' and partly covered with loess. The central part is divided by a rift valley with pure sandy sediments. Its location on the northern fringe of German highlands is very exposed to the long-range transported air pollutants, which reflect in high deposition rates. Therefore, the soils on sandstones and pure sand sediments are generally very acid and nutrient poor dystric cambisols [21], on loess-dominated sites eutric cambisols and haplic luvisols. The Solling itself is an area with a relatively low population density and no major industrial facilities. The woodland history traces back into the $16^{\text {th }}$ century and today the forests cover $42 \%$ of the investigation area. It is distributed among 26\% deciduous, $11 \%$ coniferous, and 5\% mixed forests. Following the classification of [22] the Fig. (1) shows the spatial distribution of the land-use classes in the Solling based on the CORINE Land Cover 2000 dataset. The area belongs to the suboceanic climate. The so-called "Hochsolling" is an area which belongs to the montane belt with high annual precipitation and cold winters with much snow. The AMT for the period 1950-2000 in the investigation area lies between $6.5^{\circ} \mathrm{C}$ and $9^{\circ} \mathrm{C}$, the mean annual precipitation between $600 \mathrm{~mm}$ and about $1000 \mathrm{~mm}$ [23].

\section{Model Description}

Many physically-based hydrologic models have been developed to simulate the dynamic processes of evapotranspiration and soil water movement (e.g. BROOK90: [24]; CoupModel: [25]). In this paper we use the BROOK90 (Version 4.4e) model - a 1D-Soil-Vegetation-Atmosphere Transfer (SVAT) Model [24, 26] to simulate the water balance of a forest stand. BROOK90 has been developed to be applicable to different and changing land use. It simulates interception by a single layered (horizontally homogeneous) stand, evapotranspiration, soil water, and a streamflow consisting of surface runoff, bypass flow, down slope flow, and base flow. The soil water transport is described by the Darcy-Richard equation. BROOK90 is a detailed, processoriented model that can be used as a tool to investigate the potential effects of tree species, soil type, and climate scenarios on drought stress. BROOK90 has been used to study the soil water budget of forest stands over a broad set of study sites (e.g. [27-31]).

\section{Calculation of Drought Stress}

In many investigations the relative transpiration index (RTI) was used as an indicator of the critical state of soil water resources availability. RTI describes the ratio of actual transpiration to potential transpiration [29, 32, 33]. The other commonly used indicator is the dynamic relative extractable soil water, $\operatorname{REW}(\mathrm{t})$. It could be calculated as the ratio of actual to maximum extractable water according to [34]:

$$
R E W(t)=\frac{\theta_{v}(t)-\theta_{r}}{\theta_{f c}-\theta_{r}}
$$

where $\theta_{\mathrm{v}}\left[\mathrm{m}^{3} \mathrm{~m}^{-3}\right]$ is the actual (correspondingly - daily) volumetric (subscript "v") soil water fraction; $\theta_{\mathrm{fc}}\left(\mathrm{m}^{3} \mathrm{~m}^{-3}\right)$ is the maximum soil water content extractable by plants (subscript "fc" means field capacity), and $\theta_{\mathrm{r}}\left(\mathrm{m}^{3} \mathrm{~m}^{-3}\right)$ is the residual soil water content.

For various forest ecosystems types [35] and [36] have identified $40 \%$ of REW in the rooting zone as a critical limit, below which transpiration and gross primary production are sharply reduced by drought. The drought stress duration (DSD) is calculated as follows:

$$
D S D=\sum_{i=1}^{365}\left\{\begin{array}{cc}
1 & \text { if } \\
0 & \text { else }
\end{array} \quad \text { REW }<0.4\right.
$$

\section{Climate Scenarios}

BROOK90 needs daily inputs of precipitation, maximum and minimum air temperature, solar radiation, water vapour pressure, and wind speed. To describe the dynamic nature and uncertainties of drought stress during the $21^{\text {st }}$ century for each combination of site, soil, and tree species, two different climate scenarios (SRES A1B and B1) were applied. The scenarios calculations for the period of 2001-2100 as well as $20^{\text {th }}$ century scenario C20 for the period of 1960-2000 were done by coupled general circulation model - ocean model, ECHAM5-MPIOM, as defined in German framework program "klimazwei". The modeled data are downscaled using Climate Local Model (CLM) [37] to a spatial resolution of $0.2^{\circ} \times 0.2^{\circ}$. The daily mean values of climate variables for $\mathrm{A} 1 \mathrm{~B}, \mathrm{~B} 1$ and for $\mathrm{C} 20$ with two runs per scenario are obtained from CERA-database [38]. For all variables the time series of run 1 and 2 of $\mathrm{A} 1 \mathrm{~B}$ and $\mathrm{B} 1$ are merged with correspondent runs of $\mathrm{C} 20$ so that continuous time series from 1960 to 2100 are built for both runs of A1B and B1. Following notation is assumed in further analysis: $\mathrm{A} 1 \mathrm{~B} \_1, \mathrm{~A} 1 \mathrm{~B} \_2$ and $\mathrm{B} 1 \_1, \mathrm{~B} 1 \_2$ are correspondingly the merged runs 1 and 2 of $\mathrm{C} 20-\mathrm{A} 1 \mathrm{~B}$ and $\mathrm{C} 20-\mathrm{B} 1$. The simple $\mathrm{A} 1 \mathrm{~B}$ and $\mathrm{B} 1$ denote respective merged scenarios averaged over the two runs.

\section{Soil Profiles and Parameters}

For the spatially distributed simulation we used the digital soil map of Germany at a scale of 1:1000000 [39] and the digital metadata corresponding to the above-noted soil map. This map is subdivided accordingly to the main land cover types (forest, cropland, and grassland). Only the forest soils were selected and intersected with the geometries of the climate data. The generated database contains 15 different soil types with descriptions of physical and chemical properties for their different horizons. For the simulation of the soil water fluxes, the parameters of the water retention curve and the hydraulic conductivity function were deduced from soil texture with the modified pedotransfer function [40] for each horizon (Table 1). The Clapp and Hornberger values for porosity are too low for most forest soils. Therefore, we used the correction of [41], which depends on bulk density and organic matter. For soil textural 


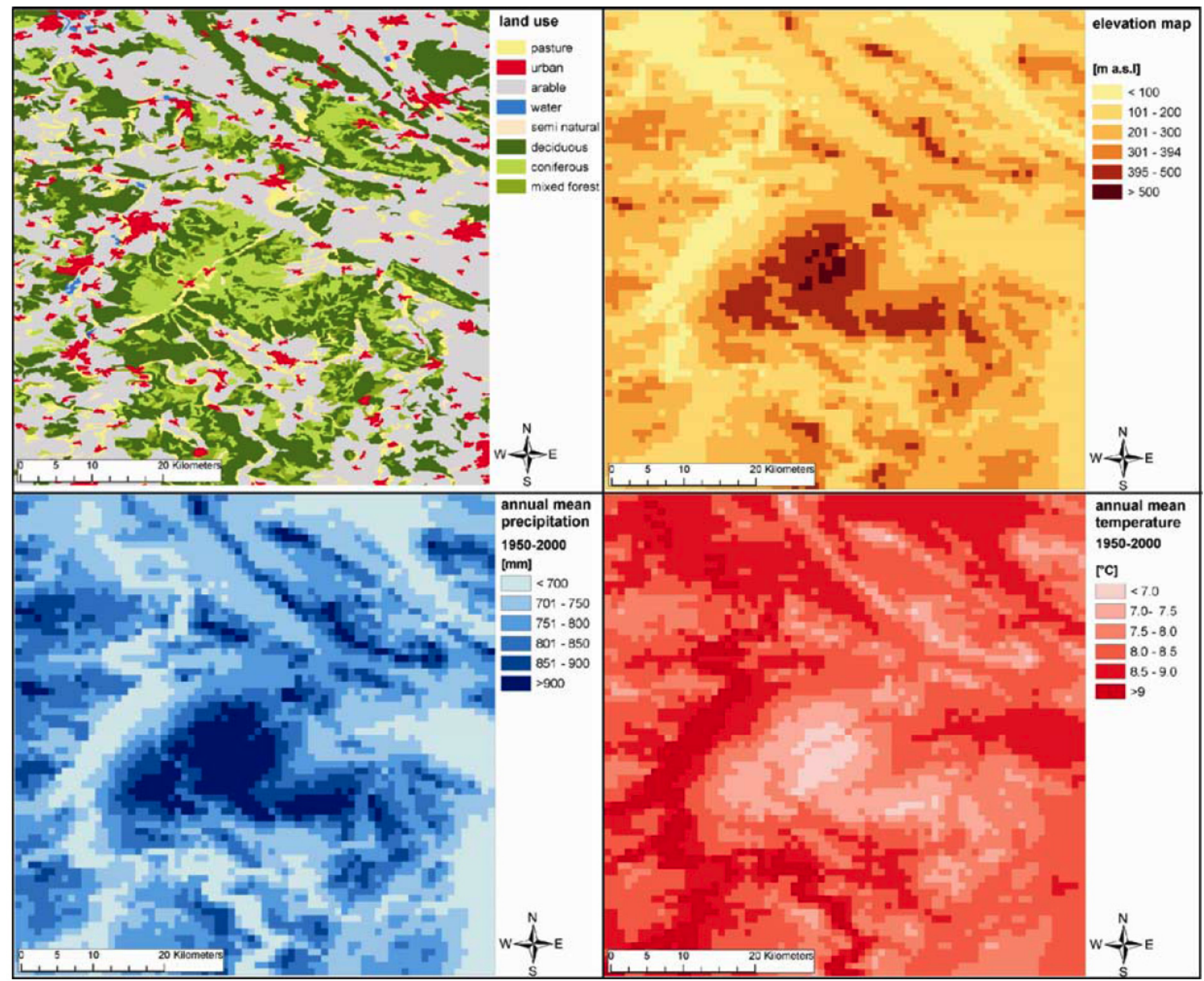

Fig. (1). Map of Solling site showing the different land-use classes (left upper panel), elevation (right upper panel), the annual mean precipitation (left lower panel) and the annual mean temperature (right lower panel). Data sources: [23] and CORINE Land Cover 2000; Umweltbundesamt, DLR-DFD 2004.

classification we used the program Triangle [42]. Because BROOK90 uses the water potential of the top layer to estimate soil evaporation, large differences in the estimated thickness of the first soil horizon affect the ratio of soil evaporation to transpiration. Therefore, we parameterized the forest floor with the hydraulic parameters for peat [43].

\section{Estimating Root Parameters}

In general, the architecture of root systems is mainly influenced by the parent material, the soil type, bulk density, the chemical soil conditions, the depth of ground water, and the species and age of trees. Despite the published results of experimental researches, the rooting depth and root distribution in the soil profile are difficult to estimate and therefore are critical model parameters. For the estimation of the effective rooting depth (ERD) we used the linking rule from [13]. The relative root density was modeled as a function of soil depth using a modification of the second equation from [24]:

$$
f=1-0.5^{z / h}
$$

where $f$ is the fraction of roots above depth $\mathrm{z}$, and $\mathrm{h}$ is the depth at which $f=0.5$. We recalculated $h$ from the effective rooting depth (ERD) and a constant, calculated from $\mathrm{h}$ and ERD given in [24]:

$$
h=\frac{E R D}{6.64}
$$

\section{Specific Parameters for Tree Species}

For most parameters we used the values from standard BROOK90 parameter set for temperate forest [26]. Table 3 provides an additional overview of sensitive factors for the two tree species used in this study. The leaf area index (LAI) of a stand is a key parameter in modeling the canopy characteristics. Defined as the projected leaf area per unit surface area of the ground, it exhibits a strong effect on the water budget of forest ecosystems and therefore is used as an input for process-based hydrology models [24]. It is a 
Table 1 Soil Hydraulic Parameters by Texture Class from [40] at Saturation (Subscript s) and at the Upper Limit of Available Water (Subscript fc) Taken from [24]

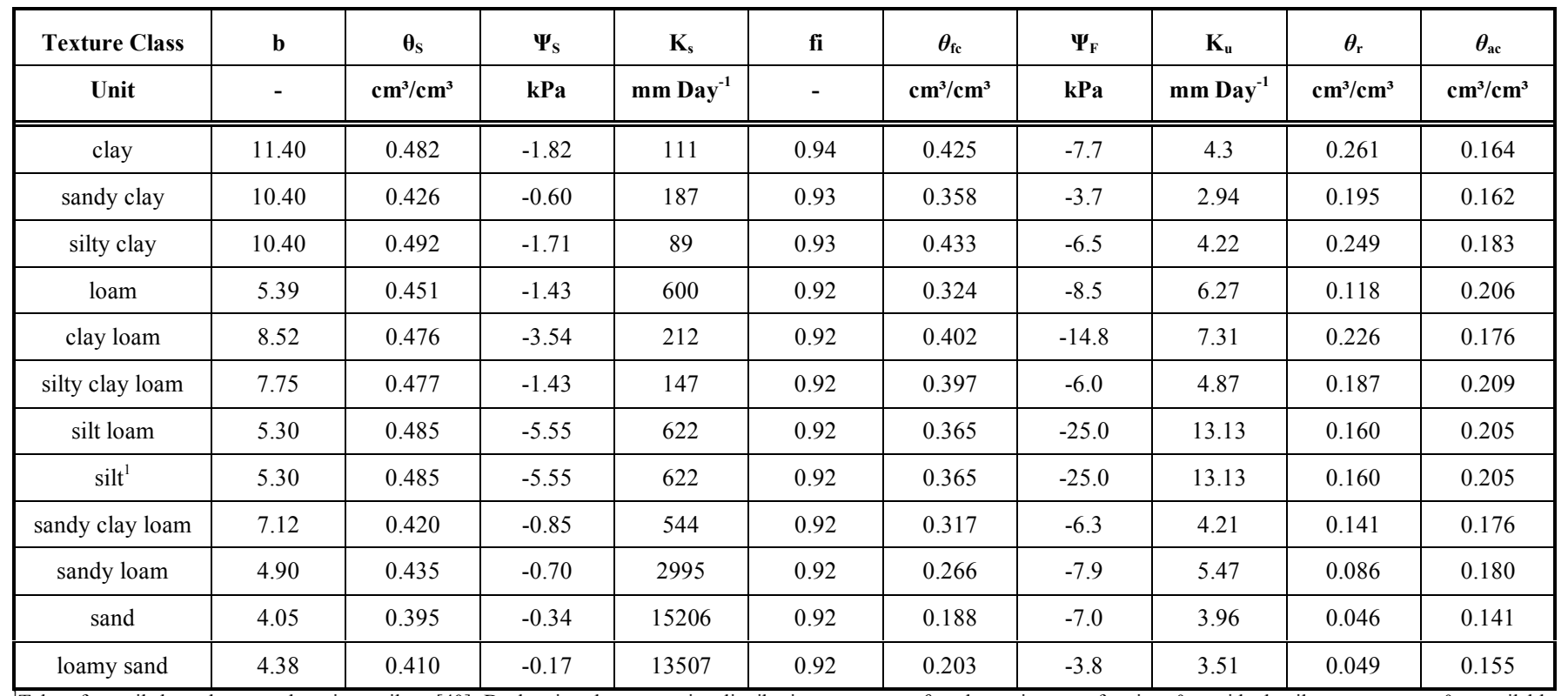

Taken from silt loam because there is no silt at [40]. Declaration: b: a pore-size distribution parameter; $\theta$ : volumetric water fraction; $\theta_{\mathrm{r}}$ : residual soil water content; $\theta_{\mathrm{ac}}$ : available water fraction; $\psi$ : the matrix potential; K: hydraulic conductivity; fi: Clapp-Hornberger inflection point.

variable depending on stand structure, tree species and age. Our modeling approach is based on the equation described by [44]:

$L A I=\frac{M_{l i t} \cdot\left(1+F_{a b s}\right) \cdot S L A}{F_{t}}$

where $\mathrm{M}_{\text {lit }}$ is the annual foliage litterfall $\left(\mathrm{kg} \mathrm{m}^{-2} \mathrm{a}^{-1}\right)$, SLA is the one-sided specific leaf area of foliage $\left(\mathrm{m}^{2} \mathrm{~kg}^{-1}\right)$ (Table 2), $F_{t}$ is the annual foliage turnover rate $\left(\mathrm{kg} \mathrm{a}^{-1}\right)$ and $F_{a b s}$ is the fractional mass loss on abscission $\left(\mathrm{F}_{\mathrm{abs}}=0.15\right.$, [44]). Assuming that there is an exponential relationship between temperature and foliage turnover $\left(\mathrm{F}_{\mathrm{t}}=\mathrm{a} \exp (\mathrm{b} \cdot \mathrm{T})[45]\right)$, we can rewrite equation 5 as follows:

$$
L A I=\frac{M_{l i t} \cdot\left(1+F_{a b s}\right) \cdot S L A}{a \cdot \operatorname{EXP}(b \cdot T)}
$$

$\mathrm{M}_{\text {lit }}$ can be estimated with a modified allometric function for each tree species [45]:

$$
M_{l i t}=\operatorname{EXP}\left(b_{0}+b_{1} \cdot \ln (D B H)+b_{2} \cdot T\right) \cdot(n / 10000)
$$

where $n$ is the number of trees per hectare, $\mathrm{DBH}$ is the diameter at breast height $(\mathrm{cm}), \mathrm{T}$ is $\operatorname{AMT}\left({ }^{\circ} \mathrm{C}\right)$, and $\mathrm{b}_{0}$ to $\mathrm{b}_{2}$ are tree specific regression parameters.

Replacing $\mathrm{M}_{\mathrm{lit}}$ in (6) with (7) LAI can be calculated as

$$
L A I=\frac{e^{\left(b_{0}+b_{1} \cdot \ln (D B H)+b_{2} \cdot T\right)}(n / 10000) \cdot\left(1+F_{a b s}\right) \cdot S L A}{a \cdot \operatorname{EXP}(b \cdot T)}
$$

At a AMT of about $0^{\circ} \mathrm{C}$ we set the parameter "a" as foliage turnover rate for $0^{\circ} \mathrm{C}\left(\mathrm{F}_{\mathrm{t}, 0}\right)$.

$L A I=\frac{e^{\left(b_{0}+b_{1} \cdot \ln (D B H)\right)}(n / 10000) \cdot\left(1+F_{a b s}\right) \cdot S L A}{F_{t, 0}}$

In regions with an AMT about $0^{\circ} \mathrm{C}$ (Northern Sweden and Northern Finland) turnover rates from amounts of litter and living needle biomass of Norway spruce and Scots pine show values between 0.1 and $0.15 \mathrm{a}^{-1}[46,47]$. Therefore we set this parameter to 0.125 for all coniferous tree species, knowing that this is a critical model parameter. Because the turnover of needles was estimated from litterfall and living biomass we do not take into account the fractional mass loss on abscission for coniferous forests. The parameter for the litterfall model was taken from [48]. For modeling the intraannual variability of LAI, a growing-season phenological model was introduced to simulate the influence of temperature on the start $[49,50]$ and the end [51] of the growing season. The result is a model to simulate the temporal and spatial LAI dynamics. The approach allows the robust computation with a low parameter demand.

For the estimation of stem area index (SAI) we used the functions after [52] and [28]:

$S A I=a \cdot D B H^{b} \cdot(n / 10000) \cdot c$

where $\mathrm{n}$ is the number of trees per hectare, $\mathrm{DBH}$ is the diameter at breast height $(\mathrm{cm}), \mathrm{a}$ and $\mathrm{b}$ are regression parameters $(a=0.0192 ; b=2.0947$ for beech and $a=0.0553$; $\mathrm{b}=1.9769$ for spruce) and $\mathrm{c}$ is the correction coefficient for projected stem area $(\mathrm{c}=0.5)$.

\section{Target Diameter Harvesting Scenarios}

To estimate the effects of TDH on drought stress under climate change conditions we run three scenarios for each tree species. As reference unmanaged stands for beech (be1) and spruce (sp1) we use mature stands of the second yield class [53] with a DBH correction according to [54]. In the second variant of beech (be2) all trees are harvested with $\mathrm{DBH} \geq 60 \mathrm{~cm}$. In the third variant (be3) the target diameter for harvesting was $\mathrm{DBH} \geq 50 \mathrm{~cm}$. The two different utilisation scenarios for spruce are harvesting all trees with $\mathrm{DBH} \geq 45 \mathrm{~cm} \mathrm{(sp2)}$ and $\mathrm{DBH} \geq 40 \mathrm{~cm}$ (sp3). The diameter distribution and the effects of these harvesting scenarios on 
Table 2. Descriptive Statistics of Specific Leaf Area $\left[\mathrm{m}^{2} \mathrm{~kg}^{-1}\right]$ for Chosen Tree Species

\begin{tabular}{|c|c|c|c|c|c|c|c|}
\hline Tree Species & Mean & Median & Min & Max & sd & cv \% & n \\
\hline \hline Norway Spruce & 4.43 & 4.48 & 3.20 & 5.65 & 0.58 & 13.18 & 34 \\
\hline European Beech & 21.01 & 21.29 & 13.9 & 24.72 & 2.43 & 11.57 & 38 \\
\hline
\end{tabular}

Data sources: [56-66]. Declaration: sd: standard deviation, cv: coefficient of variation.

Table 3. Stand Characteristics and Model Parameters for Different Harvest Intensities of Norway Spruce and European Beech

\begin{tabular}{|c|c|c|c|c|c|c|c|c|}
\hline $\begin{array}{c}\text { Parameter } \\
\text { Variant }\end{array}$ & Unit & \multicolumn{3}{|c|}{ Norway Spruce } & \multicolumn{3}{|c|}{ European Beech } & Source \\
\hline age & years & 90 & 90 & 90 & 120 & 120 & 120 & {$[53]$} \\
\hline stand density & tree $\mathrm{ha}^{-1}$ & 371 & 294 & 222 & 202 & 171 & 131 & {$[53]$} \\
\hline tree height & $\mathrm{m}$ & 27.5 & 26.8 & 26.1 & 30.3 & 30.2 & 29.3 & {$[53]$} \\
\hline max leaf conductance & $\mathrm{cm} \mathrm{s}^{-1}$ & 0.53 & 0.53 & 0.53 & 0.53 & 0.53 & 0.53 & {$[24]$} \\
\hline max leaf area index & $\mathrm{m}^{2} \mathrm{~m}^{-2}$ & 6.6 & 4.6 & 3.1 & 7.2 & 5.1 & 3.4 & eq 9 \\
\hline relative winter LAI & {$[-]$} & 0.8 & 0.8 & 0.8 & 0.0 & 0.0 & 0.0 & {$[28]$} \\
\hline SAI & $\mathrm{m}^{2} \mathrm{~m}^{-2}$ & 1.40 & 0.96 & 0.63 & 0.55 & 0.45 & 0.29 & eq 10 \\
\hline albedo & {$[-]$} & 0.14 & 0.14 & 0.14 & 0.14 & 0.14 & 0.14 & {$[24]$} \\
\hline albedo with snow & {$[-]$} & 0.14 & 0.14 & 0.14 & 0.23 & 0.23 & 0.23 & {$[24]$} \\
\hline
\end{tabular}

Declaration: SAI: stem area index, DBH: diameter at breast height.

the mean stand characteristics are modeled with the forest simulator BWinPro7 [55]. The resulting stand parameters are summarized in Table $\mathbf{3}$.

\section{Preprocessing of GIS Coverage's and Input Datasets}

We used the spatial information to produce a "master table" for model runs with the unique attributes of each coverage within the model area. The first step was to construct this table in ArcGis (Version 9.2; ESRI inc., Redlands, CA), which is the unique intersection of the climate, soil and land-use GIS-data layers. In the second step the constructed dataset is used for the initialization of the model runs. The BROOK90 simulations were only run for forest sites. To simulate the mixed stands with equal shares of beech and spruce the simulations were carried out for pure spruce and beech stands separately and the results were averaged with correspondent (in this case - equal) shares [27].

\section{Start and Boundary Conditions}

The simulation period started on the 01.01.1960, whereby the evaluations were performed for the following 30-years periods: P0: 1981-2010, P1: 2011-2040, P2: 20412070, P3: 2071-2100. Due to the long initialization time from 1960 to the first analysis period the soil profiles were assumed to be saturated at the beginning, with an initial matrix potential of $-10 \mathrm{kPa}$ for all locations and horizons. To speed up the calculations, the partial differential equations were solved with a maximum of 20 iterations per day. The minimum allowed iteration time step for BROOK90 is " 2 " [26]. The maximum change in soil wetness or saturation fraction for any layer in iteration was set to $0.5 \%$. In some very rare cases this parameter was automatically changed when there was a serious water balance problem $(>0.006$ $\mathrm{mm})$. For all soils at the lower border of the soil $(2 \mathrm{~m})$ free drainage was accepted.

\section{RESULTS AND DISCUSSION}

\section{Climate Conditions}

To characterize the projected climate conditions in $21^{\text {st }}$ century in Solling area the CLM-data were post-processed according to the recommendations of [67]. The data of A1B_1, A1B_2, B1_1 and B1_2 are aggregated to annual means (sums in case of precipitation). Spatial averaging over the 9 CLM grid points to represent the study area is carried out for all mentioned climate characteristics.

The spatial variations within the chosen area are very low so that the spatial means are assumed to be representative. To describe the tendencies of climate development the spatial mean values are averaged over the 30 -years periods: P0-P3 and relative differences are calculated: $\Delta \varphi \mathrm{i}=\left(\varphi_{\mathrm{i}}-\varphi_{0}\right) /$ $\varphi_{0} * 100 \%$, where $\varphi_{\mathrm{i}}$ is the 30 -years mean value of the spatially averaged climate variable (air temperature or precipitation) for the climatic period $i=1,2,3$. The analysis of climate scenarios data shows (Fig. 2) for both scenarios an 
increase of precipitation to $\Delta \mathrm{P}_{1} \approx 6 \%$ and then a slight monotone decrease towards 2100 to $\Delta \mathrm{P}_{3} \approx 5 \%$. However, air and soil temperatures increase monotonically and rather strongly towards $\mathrm{P} 3$ with $\Delta \mathrm{T}_{3}>37 \%$ in $\mathrm{A} 1 \mathrm{~B}$ and $\Delta \mathrm{T}_{3}>24 \%$ in B1 (Fig. 3).

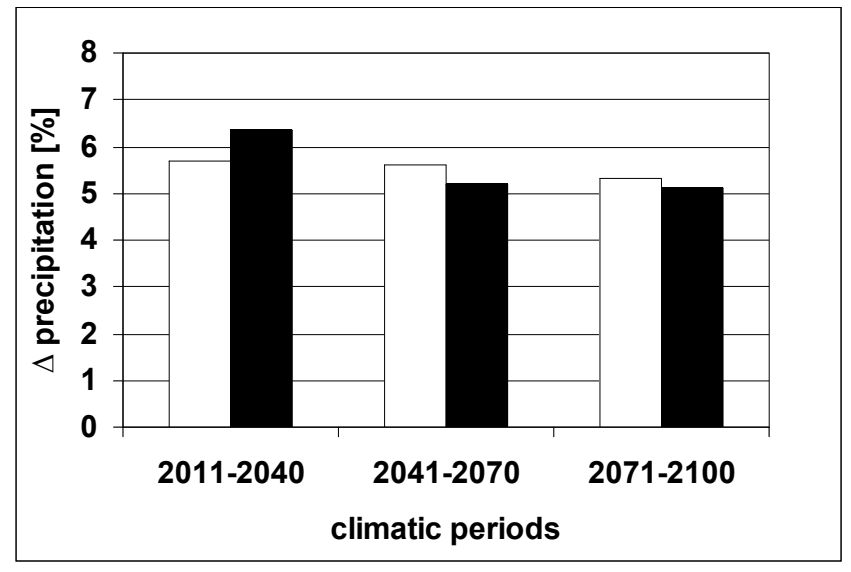

Fig. (2). The changes of annual mean values of precipitation sum averaged over 30 -years climatic periods relatively to the reference period ( $\mathrm{P} 0=1981-2011)$ for two SRES scenarios: $\square$ : A1B and $\mathbf{m}$ : B1.

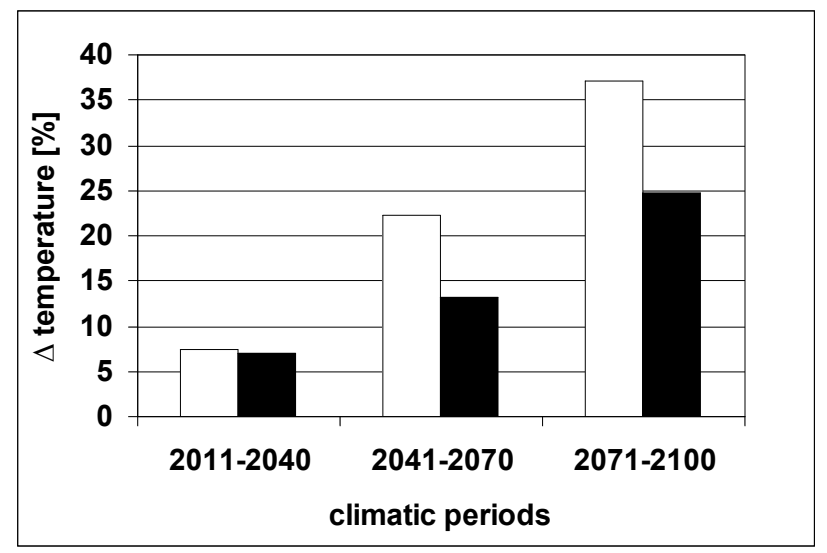

Fig. (3). The changes of annual mean values of temperature averaged over 30-years climatic periods relatively to the reference period $(\mathrm{P} 0=$ 1981-2011) for two SRES scenarios: $\square$ : A1B and $\mathbf{m}:$ B1.

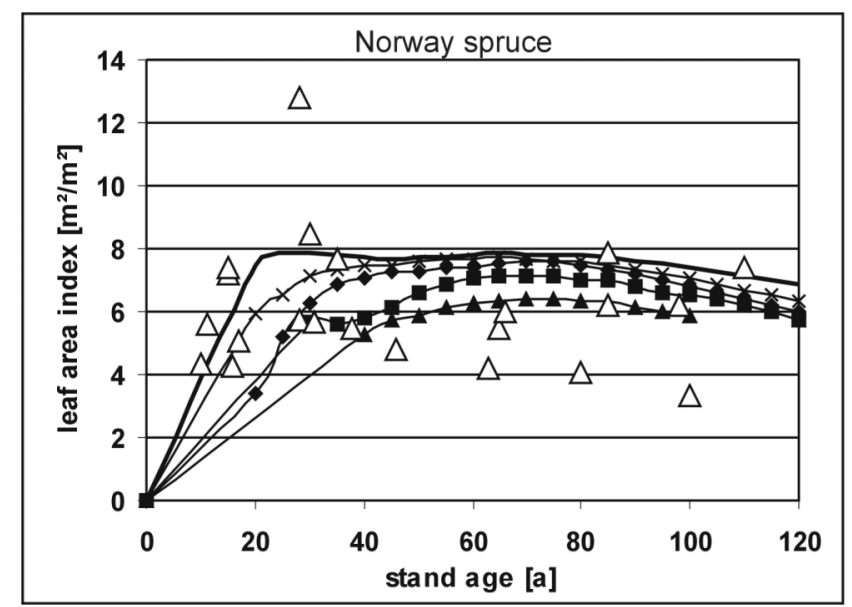

Fig. (4). Simulated long-term dynamic of leaf area index compared with literature data (left site: spruce and right site: beech). Data sources: $[28,56,68-72]$. 

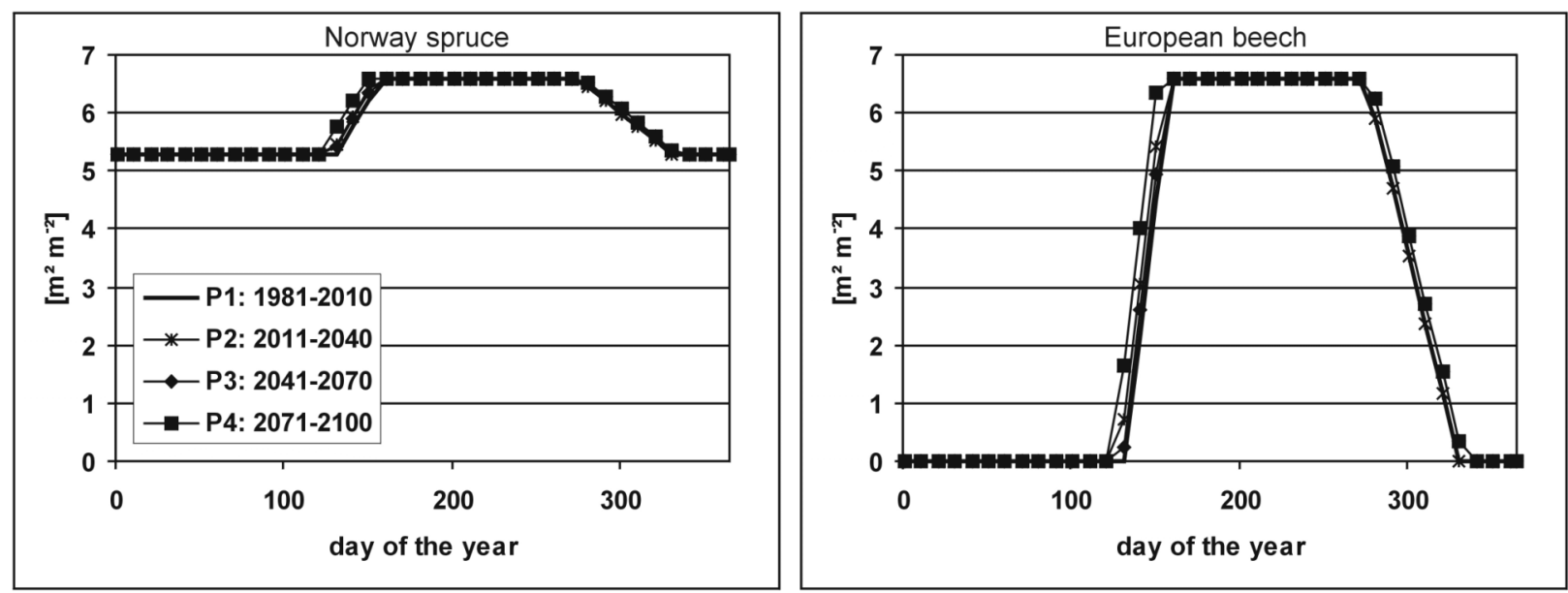

Fig. (5). Simulated seasonal variation of leaf area index for spruce and beech sites under climate change conditions in the investigation area (left site: spruce and right site: beech).

Table 4. Example for the Relative Vertical Root Distribution by Tree Species and Soil Texture Up to the Effective Rooting Depth

\begin{tabular}{|c|c|c|c|c|c|c|c|c|}
\hline $\begin{array}{c}\text { Depth } \\
\mathbf{c m}\end{array}$ & \multicolumn{4}{|c|}{ Norway Spruce } & \multicolumn{4}{|c|}{ European Beech } \\
\hline 20 & 0.23 & 0.22 & 0.20 & 0.24 & 0.19 & 0.19 & 0.16 & 0.22 \\
\hline 30 & 0.15 & 0.15 & 0.15 & 0.14 & 0.14 & 0.14 & 0.13 & 0.15 \\
\hline 50 & 0.06 & 0.07 & 0.08 & 0.05 & 0.08 & 0.08 & 0.08 & 0.07 \\
\hline 60 & 0.04 & 0.04 & 0.05 & 0.03 & 0.06 & 0.06 & 0.07 & 0.05 \\
\hline 70 & 0.03 & 0.03 & 0.04 & 0.02 & 0.04 & 0.04 & 0.05 & 0.03 \\
\hline 80 & 0.02 & 0.02 & 0.03 & 0.01 & 0.03 & 0.03 & 0.04 & 0.02 \\
\hline 120 & - & - & 0.01 & - & 0.01 & 0.01 & 0.02 & - \\
\hline 130 & - & - & 0.01 & - & 0.01 & 0.01 & 0.01 & - \\
\hline 140 & - & - & - & - & - & 0.01 & 0.01 & - \\
\hline 150 & - & - & - & - & - & - & 0.01 & - \\
\hline 160 & - & - & - & - & - & - & 0.01 & - \\
\hline 170 & - & - & - & - & - & - & 0.01 & - \\
\hline 180 & - & - & - & - & - & - & - & - \\
\hline 190 & - & - & - & - & - & - & - & - \\
\hline
\end{tabular}

A comparison of tree species effects on DSD is given in Fig. (6). The plotted values are area weighted average values for spruce and beech in the investigation area.

The Fig. (6) clearly demonstrates that under the "present climate conditions" the spruce stands have a higher drought stress duration than the beech stands, due to their higher winter LAI values (Table 3) and shallower root system [13].
The differences between the tree species are substantially smaller in the subsequent periods. On the one hand this could be an effect of rising temperatures associated with climate change and leading to a longer vegetation period (Fig. 5). These changes are better pronounced for beech than for spruce because of the higher differences between their winter and summer LAI (see Table 3). On the other hand 


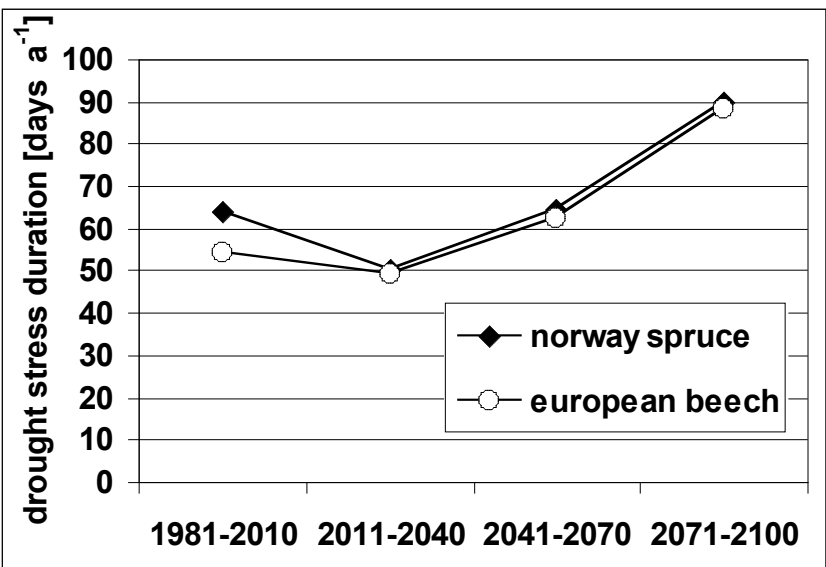

Fig. (6). Scenarios of drought stress duration (days per year) for the different tree species, SRES scenario A1B and forest management variants sp1 and be1. a further impact results from the increment of precipitation (Fig. 2), which will not be normal distributed over the year. The climate data for study area shows a clear increase in winter precipitation and a decrease in summer precipitations. By the higher amounts of winter precipitation the soil water storage could be totally refilled. Under these climate conditions and soils with relatively low water storage capacity the restore is nearly independent from the LAI in the winter.

At this point it must be mentioned that the available soil water content of the forest soils derived from the digital soil map of Germany in the Solling region [39] could raise a problem for the assessment of absolute drought stress. Comparing these values with other investigations in the same area [73] the field capacity of the soils is underestimated. Most probably the solifluction layer of loess material with the loamy texture and relatively high clay- and relatively low stone content is underrepresented in the current scale of the used soil map. Therefore the absolute drought stress duration

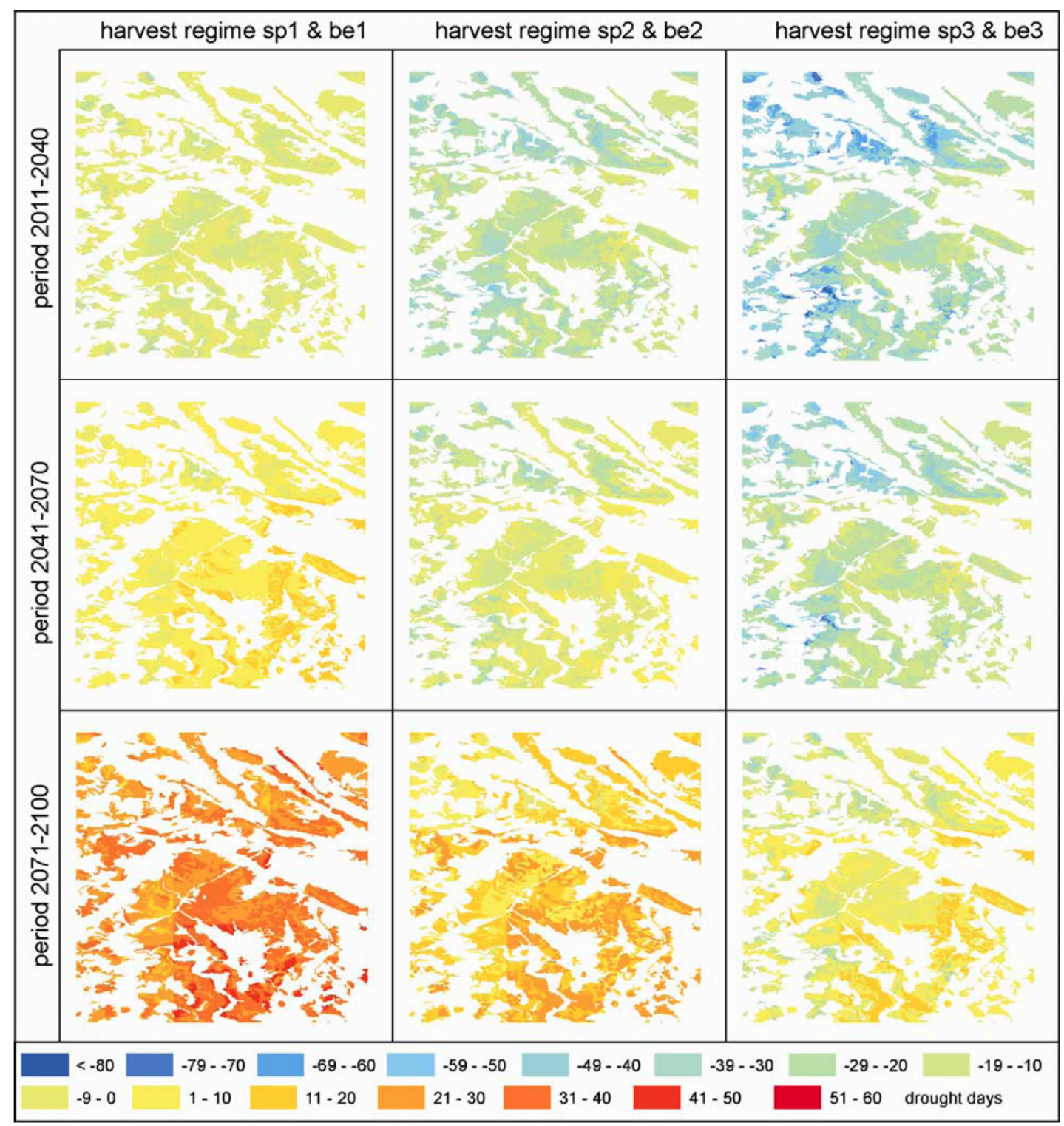

Fig. (7). Scenarios of spatial and temporal drought stress variation in forest ecosystems for different target diameter harvesting regimes under A1B climate change conditions, presented as mean yearly differences of drought duration for a given period. 


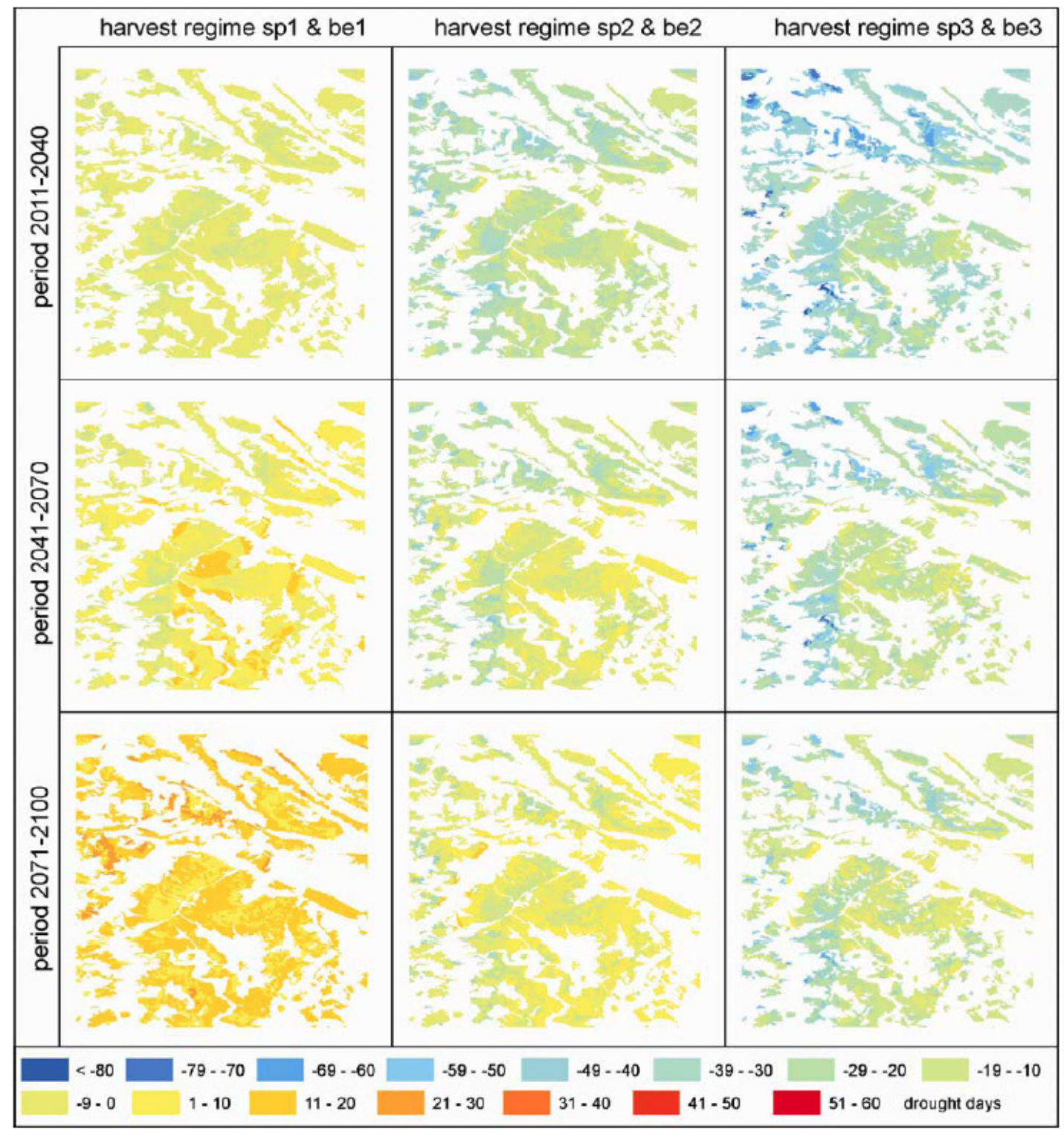

Fig. (8). Scenarios of spatial and temporal drought stress variation in forest ecosystems for different target diameter harvesting regimes under B1 climate change conditions, presented as mean yearly differences of drought duration for a given period.

seems to be slightly overestimated for this region. For example in 2003 [35] found water stress durations of 28 to 172 days in various forest ecosystems in Europe. However for a further discussion of temporal and spatial trends the dataset is sufficient.

When estimating the trends of DSD in $21^{\text {st }}$ century (Figs. 7, 8) comparing to present conditions, i.e. comparing the projected drought for periods $1,2,3$ to the reference $\mathrm{P} 0$, it is obvious that the values generally decrease from P0 to P1 and sometimes even to P2 and then increase towards 2100. The decrease in drought risk in the first period could be explained by the increase of precipitation (Fig. 2). For this period the additional water flux from precipitation is higher than the increase of evaporation due to the increase of air temperature (Fig. 3). The changes at the end of the century are considerably higher than "present conditions". The changes are generally stronger under A1B (Fig. 7) than under B1 conditions (Fig. 8).
The contribution of structure changes caused by TDH to drought risks is generally higher for spruce than for beech. However, in each particular case the value and sign of these contributions are of more complicated character depending on combination of scenarios, tree species, and soil types. The spatial pattern of drought calculated considering variants $\mathrm{sp} / \mathrm{be} 2-3$ is similar to the pattern of "standard" simulation itself but shows lower values for all species and soils. A more intensive TDH strongly reduces the drought stress intensity in all periods. As expected the effect of intensive harvesting regime is very high on spruce sites with the lowest extractable soil water capacity $(<100 \mathrm{~mm})$ on sandy soils with high stone content.

The impact of TDH also shows that the main uncertainty of our approach is linked to the estimation of LAI, as the latter is highly dependent on tree species and stand structure. The results show that LAI is one of the crucial parameters determining model response of evapotranspiration, runoff and accordingly duration of drought stress [24]. We lack data 
covering the whole variety of combinations of tree species and competition situations. Thus, any general rule on LAI estimating, like we have used for this approach and the following modeling, may provide some average LAI value, but not all specific situations for different TDH regimes.

An additional uncertainty results from the impact of ground vegetation, which is not included in the simulations. Especially in forest with opened up canopy the proportion of understorey is high and consequently the evapotranspiration rate is enhanced [74, 75].

Another crucial parameter is the estimation of the effective rooting depth and the relationship between plant water status and the depletion depth of the plant rooting system. During extreme drought events plants seem to be able to adapt the depletion depth temporarily below the ERD [76], but this cannot be included in our approach. Much more work on ERD and distribution is clearly needed [24].

\section{CONCLUSIONS}

The results of present study show: (1): considerable increment of drought risks towards 2100 compared to "present climate conditions", caused by changes in intraannual precipitation distribution and increase of mean air temperature, (2): the decrease in drought risks in the first period could be explained by the increase of precipitation and the only slight increase of temperature in this period, (3): the changes are generally stronger under A1B than B1 conditions and (4): for Solling sites the changes of structure and microclimate caused by different TDH scenarios, provide a decrease of drought stress. The magnitude of this decrease could almost compensate the increase of drought risks induced by climate warming.

\section{ACKNOWLEDGMENTS}

The study was supported by BMBF within the frames of joint project "Decision Support System - Forest and Climate Change" (DSS-WuK).

\section{REFERENCES}

[1] Thiollay JM. Forest ecosystems: threats, sustainable use and biodiversity conservation. Biodivers Conserv 2002; 11: 943-46.

[2] MCPFE: State of Europe's forests. In: The MCPFE report on sustainable forest management in Europe. Edited by Europe MCotPoFi Warsaw 2007; p. 263.

[3] Hunter ML. Wildlife, forests and forestry: principles of managing forests for biodiversity. NJ: Prentice Hall 1990; p. 370.

[4] Emborg J, Christensen M, Heilmann-Clausen J. The structural dynamics of Suserup Skov a near-natural temperate deciduous forest in Denmark. For Ecol Manage 2000; 126: 173-19.

[5] Tarp P, Helles F, Holten-Andersen P, Larson JB, Strange N. Modelling near-natural silvicultural regimes for beech - an economic sensitivity analysis. For Ecol Manage 2000; 130: 187-98.

[6] Holten-Andersen P. Economic evaluation of cyclic regimes in beech (Fagus sylvatica L). Scand J For Res 1987; 22: 215-25.

[7] Nyland RD. Silviculture: concepts and applications New York: Mc-Graw-Hill 2002; p. 682.

[8] Reininger H. Zielstärken-Nutzung oder die Plenterung des Altersklassenwaldes. Vienna: Österreich Agrarverlag 1987; p. 163.

[9] Pickett STA, White PS. The ecology of natural disturbance and patch dynamics. Orlando [ao]: Acad Press 1985; p. 472.

[10] Panferov O, Sogachev A. Influence of gap size on wind damage variables in a forest. Agric For Meteorol 2008; 148: 1869-81.
[11] Adams HD, Guardiola-Claramonte MG, Barron-Gafford A, et al. Temperature sensitivity of drought-induced tree mortality portends increased regional die-off under global-change-type drought. PANS 2009; 106(17): 7063-66.

[12] IPCC. Climate Change: The physical science basis contribution of working group I to the fourth assessment report of the intergovernmental panel on climate change. Cambridge, United Kingdom and New York NY USA: Cambridge University Press 2007; p. 996.

[13] Czajkowski T, Ahrends B, Bolte A. Critical limits of soil water availability (CL-SWA) in forest trees - an approach based on plant water status vTI. Agric For Res 2009; 59(2): 87-93.

[14] Beniston M, Stephenson DB, Cristensen OB, et al. Future extreme events in European climate: an exploration of regional climate model projections. Clim Change 2007; 81: 1-95.

[15] Tebaldi C, Hayhoe K, Arblaster JM, Meehl GA. Going to the extremes: an intercomparsion of model-simulated historical and future changes in extreme events. Clim Change 2006; 79: 185-211.

[16] Leckebusch GC, Renggli D, Ulbrich U. Development and application of an objective storm severity measure for the Northeast Atlantic region. Meteorol Zt 2008; 17(5): 575-87.

[17] Christensen JH, Carter TR, Giorgi F. PRUDENCE employs new methods to assess European climate change. Eos Trans AGU 2002; 83(13): 147.

[18] Leckebusch GC, Ulbrich U. On the relationship between cyclones and extreme windstorm events over Europe under climate change. Global Pan Change 2004; 44(1-4): 181-93.

[19] Jansen M, Döring C, Ahrends B, et al. Anpassungsstrategien für eine nachhaltige Waldbewirtschaftung unter sich wandelnden Klimabedingungen - Entwicklung eines Entscheidungsunterstützungssystems Wald und Klimawandel DSS-WuK. Forstarchiv 2008; 79: 131-42.

[20] Gardiner B, Peltola H, Kellomäki S. Comparison of two models for predicting the critical wind speeds required to damage coniferous trees. Ecol Model 129: 1-23.

[21] FAO. Soil Map of the world. Legend. World soil resources report. Rome: Food and Agriculture Organization of the United Nations 1990; Vol. 1(60): p. 119.

[22] Gauger T, Haenel H-D, Rösemann C, et al. Nationale Umsetzung UNECE-Luftreinhaltekonvention (Wirkung). Abschlussbericht zum UFOPLAN-Vorhaben FKZ 20463 252. Dessau-Rosslau: Im Auftrag d Umweltbundesamtes gefördert $v$ Bundesministerium $f$ Umwelt Naturschutz u Reaktorsicherheit 2008; p. 207.

[23] Hijmans RJ, Cameron SE, Para JL, Jones PG, Jarvis A. Very high resolution interpolated climate surfaces for global land areas. Int $\mathrm{J}$ Climatol 2005; 25: 1965-78.

[24] Federer CA, Vörösmarty C, Feketa B. Sensitivity of annual evaporation to soil and root properties in two models of contrasting complexity. J Hydrometeorol 2003; 4: 1276-90.

[25] Jansson PE, Karlberg L. Coupled heat and mass transfer model for soil-plant atmosphere system. Dept civil and environmental engineering. Stockholm: Royal Institute of Technology 2004; p. 445.

[26] Federer CA. BROOK90: a simulation model for evaporation soil water and stream flow, version 3.1. Computer freeware and documentation. USDA Forest Service, PO Box 640, Durham NH 03825, USA 1995.

[27] Armbruster M, Seegert J, Feger K-H. Effects of changes in tree species composition on water flow dynamics - Model applications and their limitations. Plant Soil 2004; 264: 13-24.

[28] Hammel K, Kennel M. Charakterisierung und Analyse der Wasserverfügbarkeit und des Wasserhaushalts von Waldstandorten in Bayern mit dem Simulationsmodell BROOK90. München: Heinrich Frank 2001; vol. 185: p. 148.

[29] Müller J. Effects of drought on the water balance of selected forest sites and the evaluation of a drought risk. Schriften aus der Forstlichen Fakultät der Universität Göttingen und der Niedersächsischen Forstlichen Versuchsanstalt 2006; 142: 142-8.

[30] Schwärzel K, Häntzschel J, Grünwald T, Köstner B, Bernhofer C, Feger K-H. Fundamentals of the spatially distributed simulation of the water balance of forest sites in a low-range mountain area. Adv Geosci 2007; 11: 43-7.

[31] Wellpott A, Imbry F, Schindler D, Mayer H. Simulation of drought for a Scots pine forest (Pinus sylvestris $L$ ) in the southern upper Rhine plain. Meteorol Zt 2005; 14: 143-50. 
[32] Budagovskij A, Grigorieva N. The way to improve effectiveness of soil water resources utilization. Vod Res 1991; 1: 131-42.

[33] Klap JM, Reinds GJ, Bleeker A, de Vries W. Environmental stress in German forests: assessment of critical deposition levels and their exceedances and meteorological stress for crown condition monitoring sites in Germany. Alterrarapport Wageningen: Altera 2002; vol. 134: p. 73.

[34] García-Santos G, Bruijnzeel LA, Dolman AJ. Modelling canopy conductance under wet and dry conditions in a subtropical cloud forest. Agric For Meteorol 2009; 149: 1565-72.

[35] Granier A, Reichstein M, Breda N, et al. Evidence for soil water control on carbon and water dynamics in European forests during the extremely dry year: 2003. Agric For Meteorol 2007; 143(1-2): $123-45$.

[36] Maseyk KS, Lin T, Rotenberg E, Grünzweig JM, Schwartz A, Yakir D. Physiology-phenology interactions in a productive semiarid pine forest. New Phytologist 2008; 178: 603-16.

[37] Rockel B, Will A, Hense A. The regional climate model COSMOCLM CCLM editorial. Meteorol Zt 2008; 12(4): 347-8.

[38] Lautenschlager $\mathrm{M}$, Keuler $\mathrm{K}$, Wunram $\mathrm{C}$, et al. Climate Simulations with CLM Data Stream 3: European region MPIM/MaD World Data Center for Climate 2009; DOIs: 1 101594/ WDCC/CLM_C20_1_D3; 2 101594/WDCC/CLM_C20_2_D3; 3 101594/WDCC/CLM_A1B_1_D3; 4 101594/WDCC/CLM_A1B_ 2 D3; 5 101594/WDCC/CLM_B1_1_D3; 6 101594/WDCC/ CLM _B1_2_D3

[39] Richter A, Adler GH, Fahrak M, Eckelmann W. Erläuterungen zur nutzungsdifferenzierten Bodenübersichtskarte der Bundesrepublik Deutschland im Maßstab 1:1 000000 (BÜK 1000 N, Version 2.3). Hannover: BGR 2007; p. 53.

[40] Clapp RB, Hornberger GM. Empirical equations for some soil hydraulic properties. Water Resour Res 1978; 14(4): 601-3.

[41] Federer CA, Turcotte DE, Smith CT. The organic fraction - bulk density relationship and the expression of nutrient content in forest soils. Can J For Res 1992; 23: 1026-32.

[42] Gerakis A, Bear B. A computer program for soil textural classification. Soil Sci Soc Am J 1999; 63: 807-8.

[43] Lee TJ, Pielke RA. Estimating the soil surface specific humidity. J Appl Meteorol 1992; 31: 480-4.

[44] Law BE, van Tuyl S, Cescatti A, Baldocchi DD. Estimation of leaf area index in open-canopy ponderosa pine forests at different successional stages and management regimes in Oregon. Agric For Meteorol 2001; 108: 1-14

[45] Ahrends B. Dynamische Modellierung der langfristigen Auswirkungen des Waldumbaus von Kiefernreinbeständen auf die Kohlenstoffspeicherung im Auflagehumus saurer Waldböden in Nordwestdeutschland. Tönning, Lübeck \& Marburg: Der Andere Verlag 2008; vol. 21: p. 162.

[46] Muukkonen P. Needle biomass turnover rates of Scots pine (Pinus sylvestris $L$ ) derived from the needle-shed dynamics. Trees 2005 ; 19: 273-9.

[47] Muukkonen P, Lehtonen A. Needle and branch biomass turnover rates of Norway spruce (Picea abies). Can J For Res 2004; 34: 2517-27.

[48] Ahrends B, Meesenburg H, Döring C, Jansen M. A spatio-temporal modeling approach for assessment of management effects in forest catchments. Status and Perspectives of Hydrology in Small Basins. IAHS Publ 2010; 336: 32-7.

[49] Menzel A, Fabian P. Growing season extended in Europe. Nature 1999; 397: 659.

[50] Menzel A. Phänologie von Waldbäumen unter sich ändernden Klimabedingungen - Auswertung der Beobachtungen in den internationalen phänologischen Gärten und Möglichkeiten der Modellierung von Phänodaten. München: Forstwissenschaftliche Fakultät der Universität München und Bayerische Landesanstalt für Wald und Forstwirtschaft 1997; vol. 164: p. 147.

[51] Wilpert von K. Die Jahrringstruktur von Fichten in Abhängigkeit vom Bodenwasserhaushalt auf Pseudogley und Parabraunerde. Ein Methodenkonzept zur Erfassung standortsspezifischer Wasserstreßdisposition. Freiburger Bodenkd Abh 1990; 24: p. 184.
[52] Hörmann G. Scherzer J, Suckow F, et al. Wasserhaushalt von Waldökosystemen: Methodenleitfaden zur Bestimmung der Wasserhaushaltskomponenten auf Level II-Flächen: Bundesministerium für Verbraucherschutz. Bonn: Ernährung und Landwirtschaft BMVEL 2003; p. 92.

[53] Schober R. Ertragstafeln wichtiger Baumarten bei verschiedener Durchforstung. 4. Aufl. Frankfurt a. M.: Sauerl 1995; p. 166.

[54] Wollborn P, Böckmann T. Ein praktikables Modell zur Strukturierung des Vorrates aus Ertragstafelschätzungen. Forst und Holz 1998; 53(18): 547-50.

[55] Nagel J, Albert M, Schmidt M. Das waldbauliche Prognose- und Entscheidungsmodell BWINPro 6.1. Forst und Holz 2002; 57: 48693.

[56] Bauer G, Schulze E-D, Mund M. Nutrient contents and concentrations in relation to growth of Picea abies and Fagus sylvatica along a European transect. Tree Physiol 1997; 17: 777-86.

[57] Oleksyn J, Modrzýnski J, Tjoelker MG, Zytkowiak R, Reich PB, Karolewski P. Growth and physiology of Picea abies populations from elevational transects: common garden evidence for altitudinal ecotypes and cold adaptation. Funct Ecol 1998; 12: 573-90.

[58] Reich PB, Kloeppel BD, Ellsworth DS, Walters MB. Different photosynthesis nitrogen relations in deciduous hardwood and evergreen coniferous tree species. Oecologia 1995; 104: 24-30.

[59] Gower ST, Richards FJ. Larches: deciduous conifers in an evergreen world. BioScience 1990; 40: 818-26.

[60] Kellomäki S. Calculation of foliage mass and foliage area. In: biogenic VOC emissions and photochemistry in the boreal regions of Europe - Biphorep. In: Laurila T, Lindfors V, Eds. Research Directorate-General: Helsinki 1999; pp. 113-26.

[61] Pietsch SA, Hasenauer H, Thornton PE. BGC-model parameters for tree species growing in central European forests. For Ecol Manage 2005; 211: 264-95.

[62] Tatarinov FA, Cienciala E. Application of BIOME-BGC model to managed forests. 1 Sensitivity analysis. For Ecol Manage 2006; 237: $267-79$

[63] Leuschner C, Voß S, Foetzki A, Clases Y. Variation in leaf area index and stand leaf mass of European beech across gradients of soil acidity and precipitation. Plant Ecol 2006; 182: 247-58.

[64] Bouriaud O, Soudani K, Bréda N. Leaf area index from litter collection: impact of specific leaf area variability within a beech stand. Can J Remote Sensing 2003; 29(3): 371-80.

[65] Bartelink HH. Allometric relationships for biomass and leaf area of beech (Fagus sylvatica L.). Ann Sci For 1997; 54: 39-50.

[66] Aranda I, Pardo F, Gil L, Pardos JA. Anatomical basis of the change in leaf mass per area and nitrogen investment with relative irradiance within the canopy of eight temperate tree species. Acta Oecologica 2004; 25: 187-95.

[67] Important user information on the regional climate simulation data with CLM December 2008. Available from: http://wwwma dzm awde/fileamin/extern/SGAFiles/CLM_report_readme/clm_user_inf ormation_dec_2008pdf

[68] Salm C, van der Gon HD, Wieggers R, Bleeker A, van den Toorn A. The effect of afforestation on water recharge and nitrogen leaching in the Netherlands. For Ecol Manage 2006; 221: 170-82.

[69] Mitscherlich G. Wald Wachstum und Umwelt. Band 1: Form und Wachstum von Baum und Bestand. 2. Überarb, Auflage, Frankfurt a.M.: Sauerl 1978; p. 144.

[70] Knyazikhin Y, Mieszen G, Panferov O, Gravenhorst G. Small-scale study of three-dimensional distribution of photosynthetically. active radiation in a forest. Agric For Meteorol 1997; 88: 215-39.

[71] Nilson T, Anniste J, Lang M, Praks J. Determination of needles area indices of coniferous forest in the NOPEX region by groundbased optical measurements and satellite images. Agric For Meteorol 1999; 98-99: 449-62.

[72] Tobin B, Black K, Osborne B, Reidy B, Bolger T, Nieuwenhuis M. Assessment of allometric algorithms for estimating leaf biomass leaf area index and litter fall in different-aged Sitka spruce forests. Forestry 2006; 79(4): 453-65.

[73] Bredemeier M, Tiktak A, van Heerden K. The Solling Norway spruce site. Ecol Modell 1995; 83: 7-15. 
[74] Constantin J, Grelle A, Ibrom A, Morgenstern K. Flux partioning between understory and overstory in a boreal spruce/pine forest determined by the eddy covariance method. Agric For Meteorol 1999; 98-99: 629-43.
[75] Müller J, Bolte A, Beck W, Anders S. Bodenvegetation und Wasserhaushalt von Kiefernforstökosystemen (Pinus sylvestris L.). Verhandlungen der Gesellschaft für Ökologie 1998; 28: 407-14.

[76] Joslin JD, Wolfe MH. Fine-root growth response. Ecol Stud 2003; 166: $274-302$

(C) Ahrends et al.; Licensee Bentham Open.

This is an open access article licensed under the terms of the Creative Commons Attribution Non-Commercial License (http://creativecommons.org/licenses/by$\mathrm{nc} / 3.0 /$ ) which permits unrestricted, non-commercial use, distribution and reproduction in any medium, provided the work is properly cited. 